\title{
Pre-service teachers' competencies in a work-based learning environment
}

\author{
Reynold C. Padagas
}

Department of Liberal Arts, Criminology and Education (LACE), Jose Rizal University, \#80 Shaw Boulevard, Mandaluyong City, Philippines.

Accepted 4 September, 2018

\begin{abstract}
The study assessed and explored the pedagogical, student performance assessment, and classroom management skills of Pre-Service Teachers (PSTs) in their Work-based Learning Environment (WBLE). A sequential-explanatory mixed methods design was employed. Seventy PSTs were purposively selected as participants. To determine the three identified competencies, the study started with quantitative research method (Phase 1) using survey questionnaire containing items from various sources. After this, a qualitative data gathering method (Phase 2) using face-to-face interview and narratives was employed to further explore on the characteristics and challenges experienced by the PSTs. The findings revealed that the PSTs were generally competent in the three sets of competencies but the extent of employing all these in their WBLE says otherwise. Furthermore, their competencies, too, were not significantly related. Moreover, several challenges that beset the PSTs in their WBLE were also identified, hence, the formulation of the Triangle of Pre-Service Teachers' Attributes and Characteristics, and Competencies as basis in helping the PSTs improve their competencies as future members of the teaching workforce. The Higher Education Institutions can benefit from the results to keep improvements in the way their PSTs are being prepared for to provide quality teaching and learning among their target classes.
\end{abstract}

Keywords: Pre-service teachers, work-based learning environment, pedagogical skills, student performance assessment skills, classroom management skills.

\section{INTRODUCTION}

Adequate teacher professional development is needed to handle the changing teaching demands and fast advancing learning needs of students. Improving teacher education contributes much to the realization of the goals set for the whole educational system. Southeast Asian Ministry of Education Organization (SEAMEO) Innotech Regional Education Program (SIREP) cited that teachers are one of the main pillars of a sound and progressive society wherein they play a significant role in knowledge acquisition as well as values formation of children. The development of the best human capital lies among best teachers. As highlighted, teaching is essential as knowledge and values are passed on to students to prepare them for further education, work life and family building. Further, SEAMEO Innotech identified $21^{\text {st }}$ century teacher competencies namely: skills in pedagogy; skills in student assessment; skills in classroom management; skills in professional development; skills in professional ethics and morality; and skills in social human dimension.

There is an endless battle cry to improve the quality of education in the country. With the advent of the K-12 curriculum, public and private secondary schools are in dire need of qualified teachers who can deliver quality education. As a matter of fact, the Philippines has been lagging behind in terms of Mathematics and Science performances compared to its neighboring countries based on Trends in International Mathematics and Science Study (TIMSS). The Department of Education, being the prime mover of basic education in the country, 
was never deaf regarding such concern. Ager (2016), in his report, cited the assertions of Sec. Leonor Briones that the Department of Education (DepEd) is "hunting" for more Mathematics and English teachers because this is where the need is greatest considering the fact that 60 percent of our learners prefer the academic program. With such demands, Teacher Education Institutions (TEls) and Higher Education Institutions (HEls) offering Bachelor of Science in Secondary Education and Bachelor in Elementary Education (BEEd) must intensify its thrust towards quality education to be able to prepare the future workforce at their best.

The roles of teachers and schools are changing, and so are expectations about them (Khorooshi et al., 2016). Teachers must educate in progressively multicultural classrooms, coordinate students with particular needs, utilize ICT for teaching viably, engage in evaluation and accountability processes, and involve parents in schools. In fact, this is also true in the field of childhood teacher education not only in secondary education. In a study conducted by Kaarby and Lindboe (2016), in childhood teacher education regulations, the relevance to the field of practice is stressed, but little attention is paid to the learning environment at work. Giving importance to the utilization of work-based learning environment (WBLE) is necessary. Specific recognition of the importance of the workplace as a learning environment is needed (Kaarby and Lindboe, 2016). The TEls need to establish quality work-based learning programs because these greatly benefit students, employers, schools, and the community. The Career and Technical Education of the Public Schools of North Carolina, State Board of Education, Department of Public Instruction cited:

"Students benefit from work-based learning through establishment of a clear connection between school and work, assessment of their interests, aptitudes, and abilities while learning about the career possibilities available to them, improvement of their post-graduation employment opportunities, development and practice of positive work-related habits and attitudes including the ability to think critically, solve problems, work in teams, and resolve issues, assessment and understanding of the expectations of the workplace, establishment of professional contacts for future employment, expansion and refinement of their technical skills, participation in authentic, job-related tasks, observation of the demeanor and procedures of workplace professionals, increased motivation/appreciation for staying in school, awareness of postsecondary education opportunities."

As part of their professional preparation, Pre-service Teachers (PSTs) are exposed to public and private schools to provide them the needed experiences expected of professional teachers. These educational institutions, also known as their work-based learning environment, are rich venues to hone their various skills. It is posited that PSTs' exposure to WBLE equips them with the teacher competencies they need in the workplace. Competencies are broadly defined as a combination of cognitive, affective, motivational, volitional, and social dispositions that form the basis for performance (Zlatkin-Troitschanskaia et al., 2016).

As competencies are highly related to years of teaching experience, the PSTs are said to be trained to face tremendous challenges to be able to satisfy the learning needs of their target classes in their WBLE. In fact, recent research posits that there are missing connections between subject-matter knowledge, pedagogical competence and real-life practice in schools (Juhler, 2016). In order to develop practitioners who can serve all learners, teacher education programs must prepare teacher candidates to enter a wide range of diverse teaching environments (Johnston and Collum, 2018).

In this study, the pedagogical skills, student performance assessment skills, and classroom management skills of the PSTs were determined. The extents to which the PSTs employ these skills were also assessed. Moreover, the relationship of the three sets of competencies was also measured.

\section{Statement of the problem}

There is a need to empower the pre-service teachers in terms of their pedagogical, student performance assessment, and classroom management skills in preparation to their actual work. While the pre-service teachers are exposed to their work-based learning environment such as private and public schools to employ their theoretically acquired knowledge and skills, it is expected that they need adequate training and support in their work-based learning environment as future members of the teaching workforce. The pedagogical aspect of their profession requires not only understanding theories and concepts on how to handle their target classes but also to translate all these into tangible experiences while they are in their work-based learning environment. Moreover, their skills in student assessment require rekindling or reawakening to be able to attain balance in their assessment methods to measure cognitive, motor, and affective domains of student learning. Furthermore, their classroom management skills need enhancement to be able to prepare themselves deal with diverse learners in the future. The pre-service teachers' characteristics and attributes also play very crucial role to be able to attain improvements in the ways pre-service teachers are being prepared as members of the teaching profession. 


\section{Purpose of the study}

This study aimed to determine and explore on the preservice teachers' competencies in terms of their pedagogical, student performance assessment, and classroom management skills in a university setting. It was also the intention of this research to explore on the attitudes and characteristics of pre-service teachers in their work-based learning environment.

\section{Objectives of this study}

The following are the objectives of this study:

1. Description of the demographic profiles, attitudes and characteristics of the pre-service teachers.

2. Assessment of the pedagogical, student performance assessment, and classroom management skills of the pre-service teachers while immersed in their work-based learning environment.

3. Interrelationship of their assessed sets of competencies.

4. Exploration of the various challenges encountered by the pre-service teachers in executing their assessed sets of competencies.

\section{Research questions}

1. How are the pre-service teachers described in terms of their demographic profiles, attitudes and characteristics?

2. What is the assessment of the pre-service teachers as regards their competencies in terms of their pedagogical, student performance assessment, and classroom management skills?

3. If there is any, how significant is the relationship of the pedagogical, student performance assessment, and classroom management skills of the pre-service teachers?

4. What are the challenges encountered by the preservice teachers in employing their pedagogical, student performance assessment, and classroom management skills?

\section{Research hypothesis}

There is a positive relationship between the three identified sets of competencies namely, pedagogical, student performance assessment, and classroom management skills of the pre-service teachers.

\section{Significance of the study}

The findings of this study will be beneficial to various stakeholders responsible in the preparation of the pre-service teachers as members of the teaching workforce. Teacher Education Institutions (TEIs), as well as colleges and universities offering education courses, will be helped to be able to make curricular improvements and become more responsive to the needs of the preservice teachers. Enhancing the curriculum of teacher education will make pre-service teachers more prepared in facing their future classes as soon as they finish their programs and pass the licensure examination set by the Professional Regulation Commission (PRC). Teachers, both the new and the experienced ones, will be able to revitalize their pedagogical, student performance assessment, and classroom management skills especially now that outcomes-based education (OBE) has been fully implemented in the Philippines. Furthermore, the researcher also believes that this study will expand understanding on how significant it is to help in the formation of responsible teachers to become more capable and prepared to the actual work and impact quality teaching and learning.

\section{METHODOLOGY}

\section{Research design}

A sequential explanatory mixed methods design was used in this study. Initially, quantitative data analysis was made. The competencies of the PSTs in their WBLE in terms of their pedagogical, student performance assessment, and classroom management skills were assessed through the use of a researcher-made questionnaire rooted from the stipulated competencies of the Southeast Asian Ministry of Education Organization (SEAMEO) Innotech, validated by experts and eventually, pilot-tested. This yielded rich quantitative data vital to the formulation of course of actions that will help improve the identified competencies of the PSTs in their WBLE. The extent of how the PSTs employ their competencies in their WBLE was also determined. Moreover, a test of significant relationship between the pedagogical, student performance assessment, and classroom management skills of the PSTs was established.

Meanwhile, to enrich the findings, qualitative data collection was done through a series of face-to-face interviews and PSTs' narratives. Further, the challenges encountered by the PSTs were explored as springboard to bring about improved attributes, characteristics and competencies as future professionals of the teaching workforce. Both quantitative and qualitative strategies of inquiry, which was emphasized by the research of Kabadayi (2015) deepen the understanding about the variables studied.

\section{Sample size and sampling strategy}

The study participants were selected using purposive 
sampling. In purposive sampling, a set of criteria has been identified to qualify the pre-service teachers as study participants. They have to be either currently enrolled in the Bachelor of Elementary Education (BEED) or Bachelor of Science in Secondary Education (BSED) majoring English, Mathematics, or Social Science.

\section{Research instruments}

The pedagogical, student performance assessment, and classroom management skills of the pre-service teachers were assessed through the use of a questionnaire based from the stipulated competencies of the Southeast Asian Ministry of Education Organization (SEAMEO) Innotech, validated by experts and eventually, pilot-tested. Meanwhile, for the qualitative part of data gathering, the use of face-to-face interviews and narratives were also employed.

\section{Validity and reliability}

Since the items in the questionnaire during the quantitative data gathering were based from the SEAMEO Innotech (2010), the contents of the questionnaire were said to be valid in terms of their content. Three researchers and education specialists also validated the contents of the questionnaire. All of the items were agreed upon by the evaluators as true measures of the sets of competencies explored in this study. To make it empirically valid and reliable, the questionnaire underwent pilot testing. The Cronbach alpha calculation yielded to 0.92 , which means that the questionnaire can measure what it intends to measure.

For the qualitative phase of the study, an interview protocol was used. The researcher crafted the protocol. The protocol contains several components that included introduction to set the parameters of the interview, key questions, and closing part. The study participants were assured about the confidentiality of their responses. The key questions sought answers to personality qualities and characteristics, pedagogical skills, classroom managements skills, and student performance assessment skills. Three qualitative research professors checked and validated the protocol for content and extent of exploration.

\section{Data analysis}

To treat the quantitative data obtained from the study participants, the researcher utilized Microsoft Excel version 2010. To analyze the pedagogical, student performance assessment, and classroom managements skills of the pre-service teachers, mean score and weighted mean were used. The relationships of the three sets of competencies were determined using one-way analysis of variance (ANOVA). The demographic profile of the study participants were treated using frequency and percentage. For the qualitative data, thematic coding was used to find meanings from the transcribed interview data and narratives from the pre-service teachers.

Both the quantitative and qualitative data were treated separately and equally enriched the findings of this study.

\section{RESULTS AND DISCUSSION}

The results are presented based on the research questions investigated in this study.

\section{How are the pre-service teachers described in terms of their demographic profiles, attitudes and characteristics?}

The demographic profile of the PSTs is described in Table 1. Using purposive sampling, the study involved sixty (60) PSTs taking Bachelor of Science in Education (BSEd) (63.33\%) - major in English (33.33\%), Mathematics (16.67\%), and Social Science (13.33\%), and Bachelor in Elementary Education (BEED) (36.67\%). To further describe the PSTs, data revealed that 49 or 81.67 percent of the pre-service teachers are within the age range of 18 to 21 years old. There are 5 or 8.33 percent whose age range at 22 to 25 years old. The least count are those aged 26 to 29 years old, and 30 to 33 years old, and 34 years old and older with 2 or 3.33 percent each. As regards gender, majority of the preservice teachers are females with 51 or 85 percent respondents. There are only 9 or 15 percent males, which was supported by Kabadayi (2010) by the study showing that the vast majority of the participants (98.4\%) are female, which generally reflects current trends within the field of education. As for the marital status of the PSTs, they are all single.

Collectively, Figure 1 presents the framework designed based on the qualitative data obtained from the PSTs. The researcher illustrated it using Visio to be able to figure out the data obtained in the qualitative part. This can be utilized as a basis to further improve specific areas cited by the PSTs concerning their competencies.

The central triangle represents the attributes and characteristics of the PSTs based on their own descriptions about themselves. The three triangles attached to each of the central triangle represent the three competencies explored in this study namely, pedagogical skills, classroom management skills, and student performance assessment skills. Figure 1 further explains that the conglomeration of all the triangles make up a better foundation on improving the competencies of the PSTs as future members of the teaching workforce. 
Table 1. Demographic profile of pre-service teachers in terms of course, age and gender.

\begin{tabular}{lcc}
\hline Demographic profile & Frequency & Percentage \\
\hline Course & & \\
BSEd major in English & 20 & 33.33 \\
BSEd major in Mathematics & 10 & 16.67 \\
BSEd major in Social Science & 8 & 13.33 \\
BEEd & 22 & 36.67 \\
& & \\
Age & & \\
18-21 years old & 49 & 81.67 \\
$22-25$ years old & 5 & 8.33 \\
$26-29$ years old & 2 & 3.33 \\
30-33 years old & 2 & 3.33 \\
34 years old and older & 2 & 3.33 \\
& & \\
Gender & & \\
Female & 51 & 15.00 \\
Male & 9 & 100 \\
Total & 60 & \\
\hline
\end{tabular}

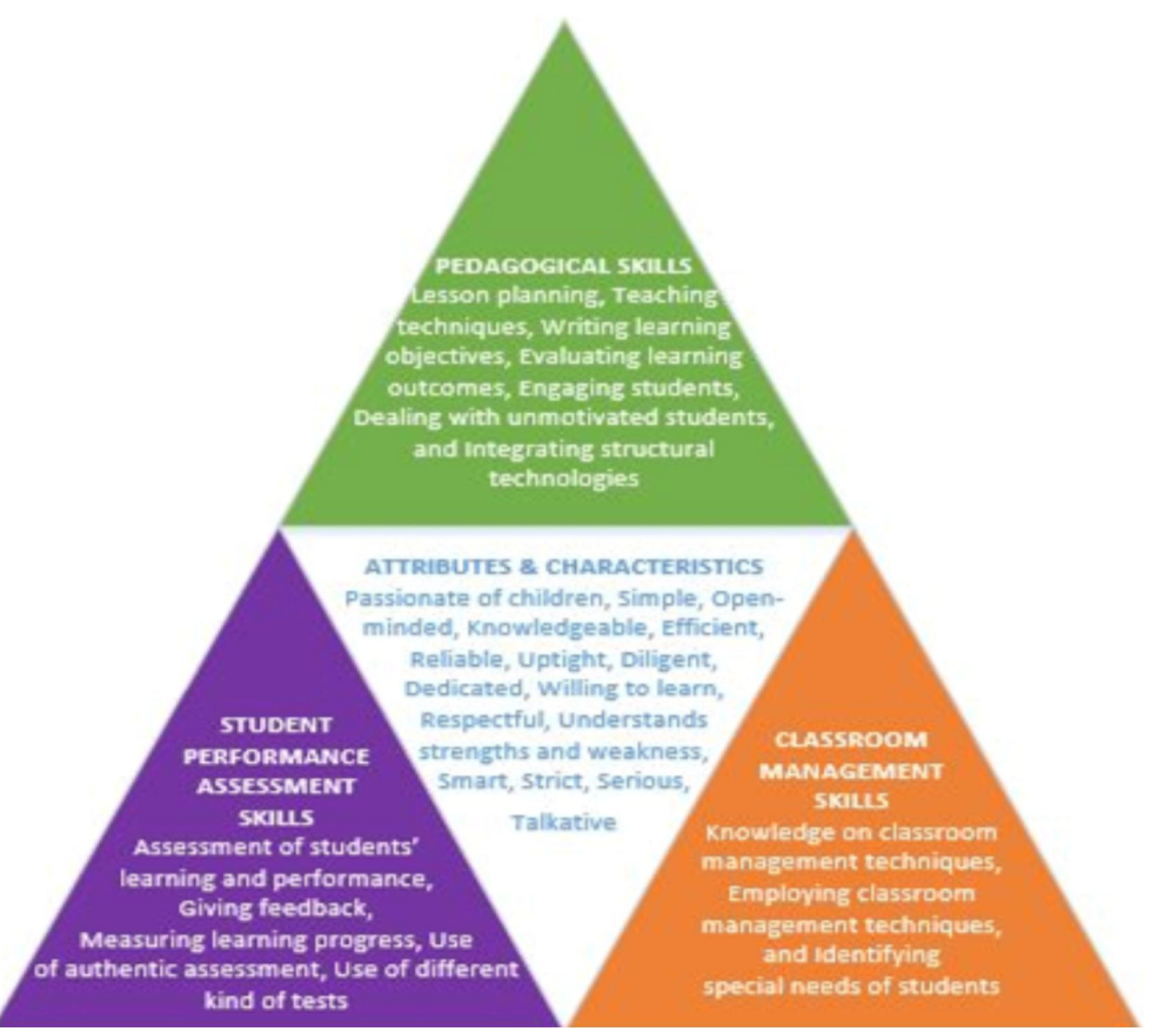

Figure 1. The triangle of the pre-service teachers' attributes and characteristics, and competencies in a WBLE. 


\section{What is the assessment of the pre-service teachers as regards their competencies in terms of their pedagogical, student performance assessment, and classroom management skills?}

The acquisition of good foundation in pedagogical skill is essential for PSTs to thrive in the field of teaching. PSTs need to heighten their pedagogical competence to effect quality instruction as they handle learners of various needs. Pedagogical competence deals with teaching skills including teaching techniques, curriculum development and assessment (Irmawati et al., 2017). Table 2 presents the mean distribution of PSTs in terms of their pedagogical skills. The data reveal that generally, the PSTs are "Competent" (WM: 4.13) in pedagogical skills.

Pedagogical skills prepare PSTs to become more adept in the practice of the teaching profession. While the PSTs rated themselves as "Competent" in this area, it is necessary to adequately train them further to be able to execute the science of teaching in the best ways possible. The focus of teacher training is the training and development of professional applicable skills, innovative and relevant to the process of teaching-learning evaluation, in the context of student-centered instruction (Popescu and Stefan, 2014). To do this, there must be a deep integration of various models and theories of education. In this way, the PSTs can be guided to practice the profession at an optimum. The teacher must be aware of several traditional and current models and then, on the basis of critical analyses of the real context, using his creativity, he must project and act specifically (Popescu and Stefan, 2014). Teacher education should build on the knowledge base that pre-service teachers already have on account of their lifelong learning in and outside of school (Van Der Valk and Broekman, 1999).

Lifelong learning, however, entails not only during the course of preparation in teacher education but also right after years of experience as professional teachers. This can be attested by Wallin et al. (2018) when they found out that learners should be supported but also allowed to self-manage their learning in order to build agency and self-regulative skills, continuous problem solving with illdefined, non-routine problems should be encouraged along with challenges that trigger learning, learners' personal transformation processes and change of identity should be supported, and expertise development should be viewed as an ongoing, context-dependent and individualized process.

Based on qualitative data gathered through face-toface interview and narratives, in lesson planning, the PSTs prepare semi-detailed and detailed lesson plans which are being checked by their cooperating teachers. It is essential to them that they identify lesson topics to help them plan for activities for their class. Lesson planning is an integral element of being a teacher. It is a blueprint for a specific daily lesson. Akkus (2015) determined pre- service social studies teachers' skills to plan and apply the activity-based teaching and contribute to their development of these skills. It was revealed in the research that pre-service teachers" skills for planning and implementing activity-based teaching improved remarkably and they gained some knowledge and skills regarding teaching profession and direction subject.

Considering the different types of learners that they have, the JRU pre-service teachers plan and prepare for varying activities. The diversity of their students is being considered to ensure that learning takes place. On the other hand, their learning objectives characterization did not meet the criteria of an effective and efficient learning objective such as specific, measurable, attainable, realistic, time-bound, rewarding, and exciting. Data analysis in the study of Schmidt (2005) revealed that these pre-service teachers held differing views of lesson planning from, each other and from their supervisor. Five themes emerged: (a) concerns about knowing how to begin to plan, (b) difficulty identifying what the children needed to learn, (c) the prominence of decisions made on the fly, (d) comparisons of thinking about teaching and planning with actual written plans, and (e) limited transfer of in-class experiences to teaching in the project. Hathaway and Fletcher (2018) highlighted the importance of preparing teachers with the awareness to appropriately discern difference among learners in order to negotiate the pedagogical challenges related to the impact of learner diversity.

In the context of teaching techniques, they utilize various strategies such as independent learning, differentiated learning, interactive or collaborative learning. Self-regulated learning has a positive effect on academic outcomes (Dignath and Büttner, 2018). Differentiated instruction is a way of recognizing and teaching according to different student talents and learning styles (Morgan, 2014). Collaborative learning involves that collaborative regulation of cognitive activities to establish common ground for the coordination of content (Tan, 2018). To ensure that students understand lessons, the pre-service teachers also translate instructions into a language students would understand. On the other hand, repeating the explanation is most likely done in order to ensure mastery of the lesson. One study participant stated that:

Leona: "I have to translate it in Tagalog. Repetitive explanation is overwhelming though."

Another PST said:

Lyza: "I translate my questions and instructions in Tagalog when needed."

Furthermore, the PSTs also use several techniques to actively engage their students in their learning process. They use techniques like humor. Authentic techniques 
Table 2. Mean distribution of pre-service teachers' pedagogical skills.

\begin{tabular}{clcl}
\hline No. & Items & WM & Verbal interpretation \\
\hline 1 & $\begin{array}{l}\text { Selecting and stating long-term goals and short-term measurable objectives based on a } \\
\text { prescribed national and/or school curriculum. }\end{array}$ & 3.90 & Competent \\
2 & $\begin{array}{l}\text { Using creative and innovative instructional strategies that are appropriate to a lesson's } \\
\text { objectives and students' abilities, interests, and learning styles }\end{array}$ & 4.20 & Competent \\
& Selecting and using appropriate resources and available technologies when teaching to suit & 4.35 & Very Competent \\
& students' abilities, interests, and learning styles & & \\
4 & Stating the objectives of lessons and skills that the students need to master in relation to & 4.10 & Competent \\
& past and future lessons & 4.18 & Competent \\
5 & Giving concise but clear directions for students to follow & 4.00 & Competent \\
6 & Explaining concepts, terms, vocabulary, and principles related to lessons clearly and & 3.92 & Competent \\
7 & provides examples when necessary & 4.22 & Very Competent \\
8 & Providing guided practice as necessary and reviews at appropriate time intervals & 4.30 & Very Competent \\
9 & Setting learning objectives and outcomes that match the students' real-life situations & 4.02 & Competent \\
10 & Sequentially and attractively teaching lessons while taking account of students' learning & 3.83 & Competent \\
11 & Providing students with learning opportunities during and outside school hours & 4.20 & Competent \\
12 & Using the appropriate medium of instruction & 4.25 & Very Competent \\
13 & Encouraging self-study & 4.07 & Competent \\
14 & Demonstrating understanding of the educational context of the classroom and the school \\
& community & 4.23 & Very Competent \\
15 & Assessing my students' learning outcomes & 4.22 & Very Competent \\
16 & Knowing the content of his/her subject matter & 4.20 & Competent \\
17 & Knowing my students & 4.03 & Competent \\
18 & Knowing how my students learn and how to effectively teach them & 4.22 & Very Competent \\
19 & Preparing clear and effective lesson plans and learning programs based on textbooks, & 4.13 & Competent \\
\hline & manuals, and other learning materials &
\end{tabular}

are also being used such as relating their lessons to real life experiences, movies, issues or news, and showbiz happenings. Visual aids and various activities are also used. Some PSTs said that:

Lyza: "Sometimes, I use humor to sustain their interest on the lesson. Usually I use 'hugot lines' about the topic because it is timely appropriate."

Leona: "I always relate my lessons to real life especially to recent movies, issues or news, showbiz happenings, etc. I also call the attention of my students who seem to be uninterested."

Likewise, if their students still seem to be uninterested, they immediately call their attention and bring them back to the lesson. Continuous classroom monitoring during activities is also being done to ensure that students are on their task. The PSTs employ various measures in dealing with unmotivated students. These measures include: roaming around during classroom activity, calling them to participate in classroom discussion, and making them group leaders.

Interestingly, the PSTs are skilled in the use of
Microsoft Word, PowerPoint presentations, Prezzi, video players like VLC and Windows Media player. They integrate technology in their classroom. They use visual aids and video presentations. It is essential that the PSTs integrate information, communication and technology in their target classes. As far as pre-service teachers are concerned, this becomes critical because they need to be equipped with the competencies for their future teaching practices (Aslan and Zhu, 2015).

Meanwhile, it can be gleaned in Table 3 that the PSTs are also "Competent" (WM: 4.17) in terms of their classroom management skills. Classroom management is as essential as other competencies in the field of teaching. The PSTs need a lot of preparation to bridge the gap between theory and practice. As such, Flower et al. (2017) emphasized that many teachers are underprepared for the behaviors that their students may bring to the classroom, resulting in challenges to teaching and learning. The PSTs defined a model classroom as a suitable learning space that is organized, clean, wellmanaged, well-lighted, and well-ventilated where students are participative and interactive, and the flow of lesson is smooth and uninterrupted. Based on the qualitative data obtained, the PSTs employ classroom 
Table 3. Mean distribution of pre-service teachers' classroom management skills.

\begin{tabular}{clll}
\hline No. & Items & WM & Verbal interpretation \\
\hline 1 & $\begin{array}{l}\text { Promptly begin instruction and complete non-instructional duties with } \\
\text { minimal loss of instruction time }\end{array}$ & 3.85 & Competent \\
2 & $\begin{array}{l}\text { Efficiently manage student behavior by ensuring that students } \\
\text { cooperatively obey classroom rules and procedures }\end{array}$ & 4.10 & Competent \\
3 & $\begin{array}{l}\text { Encourage active and ensure equitable student participation by varying } \\
\text { roles in the instructional process }\end{array}$ & 4.12 & Competent \\
4 & Establish and maintain timelines for task completion & 4.15 & Competent \\
5 & Demonstrate respect and consideration for all students & 4.62 & Very Competent \\
6 & Maintain a physical environment conducive to learning & 4.33 & Very Competent \\
7 & Communicate clearly, correctly, and coherently & 4.27 & Very Competent \\
8 & Infuse in students the value of respect and honesty & 4.50 & Very Competent \\
9 & I demonstrated the capability to manage multi-grade classes & 3.88 & Competent \\
10 & Encourage less-able students to participate in class & 4.20 & Competent \\
11 & Utilize a seat plan that will allow more advanced students to interact with & 4.00 & Competent \\
12 & their less-able counterparts & 4.52 & Very Competent \\
13 & Encourage student interaction that students have a significant degree of control over their own & 4.17 & Competent \\
14 & learning & 4.28 & Very Competent \\
15 & Support learning using group work and investigation & 4.18 & Competent \\
16 & Encourage students to be creative & 4.53 & Very Competent \\
17 & Provide basic counseling to his/her students & 4.02 & Competent \\
18 & Communicate using a variety of languages & 3.52 & Competent \\
19 & Demonstrate problem-solving, time management, presentation, & 4.02 & Competent \\
information seeking, and basic computing skills & 4.17 & Competent \\
\hline
\end{tabular}

management techniques. They make sure that their students feel that the teachers are in control. They ask their students to ensure classroom cleanliness by picking trashes as a daily routine. They also assign classroom cleaners each day. To make the class uninterrupted, unruly and talkative students are seated afar from each other and are reminded to respect the one speaking in class. As stated by a PST:

Leona: "I place my unruly and talkative students to seats which are far from each other. I always remind my students of respecting the one who's talking by listening because they will have a chance to talk as well."

On the other hand, others look at students intensely until they settle themselves. Intimidation is being used. A PST stated:

Patricia: "When my students are all very noisy, I just look at them intensely and they seem to quiet down."

Classroom management requires a skill especially that the PSTs are exposed in WBLE for just a short period of time. PSTs believe that classroom management starts by policing the students. Classroom management, to them, is essential to ensure that learning takes place. One PST highlighted that:

Patricia: "Classroom management starts with enforcing discipline among students. Students listen to authorities in school like teachers. Loud voice signifies authority but PST has soft voice so sometimes students are noisy. PST is cognizant that if classroom management fails, learning cannot happen."

Samantha: "I don't teach my class if they are still noisy and unruly. I make sure that they are all ready to listen before I start the discussion. I am also fond of letting my students do differentiated and collaborative activities."

Cleanliness in the classroom is also achieved with good classroom management. It has to become a routine. It is a significant part of the daily tasks given to students. A great deal of control is necessary. If students perceive and feel that their PSTs are in control over them, managing the classroom cleanliness is achieved. One of 
the PSTs mentioned that:

Louise: "First, you must make your students feel that you can control, if not, they will control you. Second, before starting your class let them pick up pieces of paper and make it a routine. Third, assign everyday cleaners."

However, one PST mentioned that:

Patricia: "PSTs tend to be inconsistent in administering daily tasks which could have been minimized if routine was established the first day."

Further, the PSTs identify special needs of students when their students make attention-seeking behaviors. Through observation, the pre-service teachers get to identify special needs of their learners. How their student behaves or misbehaves in class is being observed. Through the quizzes and recitation, the pre-service teachers also are able to identify the special needs of the learners.

In terms of student performance assessment as presented in Table 4, the PSTs are found to be "Competent" (WM: 4.10). The PSTs are exposed to various methods of assessing students' learning, either formative or summative assessments. For them to become more competent, their student learning assessment skills must be enhanced. Cheng et al. (2015) mentioned that classroom assessment tasks and environment are central to supporting student learning.

The PSTs utilize various assessment methodologies to determine student learning or performance. These include group activities, individualized seatwork, paper and pencil tests, writing synopsis and reaction papers, recitation, and other creative outputs like flipbook, and making comic book. They, too, employ several techniques in giving feedback to students. They give feedback directly. When their class misbehaves, they get students' attention through use of silence. Talking to students nicely is also being practiced. Other positive practices include praising students who give answers to their questions correctly and whenever they accomplish something such as getting high score in an examination.

Student learning progress are measured through assessment of scores and records of students. Through observations, results of students' written outputs and performances, multi-level test, use of report cards and monitoring outputs also are being executed. During the face-to-face interview, two of the PSTs shared:

Celeste: "I give feedbacks to them directly. If ever they make negative actions in class, I will get their attention by being silent and they know what to do."

Leona: "I praise them when they give answers correctly or when they accomplish something in class (like getting a high score in the exam). I also talk to them about their misbehaviors in a subtle and nice way.

However, aside from time constraint, the monitoring of student progress seems to be difficult at times due to the type or classification their target class has. As such, a PST stated that:

Leona: "Sometimes, I only reach lesson proper and no evaluation in a day due to time constraint considering that I handle lower sections such as 6 and 9 who need more illustrative examples."

However, the PSTs practice limited authentic assessment methodologies. Authentic assessment implies assessment of the experiences and learning processes acquired by students. As posited by Villarroel et al. (2018), authenticity has been identified as a key characteristic of assessment design which promotes learning. Time constraint is considered a factor since they are given only 50 minutes to discuss their lessons each time they meet their target classes. Some of the authentic assessment measures that they use are creative outputs such as role-playing, making flipbooks and comic books. Conversely, one of the PSTs mentioned that:

Patricia: "We are aware that they we be more objective in our assessment but rubrics has never been utilized due to lack of knowledge in preparing one."

The lack of adequate training as regards use of rubrics in assessing and evaluating their students' works seems evident. Now that written works, performance tasks, and products of learning are being taken with high consideration, there is a need to train PSTs as regards various methods of assessments, which include use of rubrics. There is a dire need to improve such skill especially now that outcome-based education (OBE) is emerging. OBE has been adopted completely by HEls governed by the Commission on Higher Education (CHED) in the Philippines.

Additionally, the PSTs employ different kinds of tests to students. These include problem-solving, true-or-false, fill-in-the-blank, matching type, multiple-choice, identification, analogy. Tests are based from their lessons. However, these projects show that the purpose of using authentic assessment and activities promoting high order thinking skills is not fully employed. The use of summative and formative tests cannot be underestimated but the need to improve use of authentic assessment measures must be facilitated to be able to measure what has to be measured validly and reliably. However, time element has been identified one factor in ensuring authentic assessment measures. One of the PSTs elaborated that: 
Table 4. Mean distribution of pre-service teachers' student performance assessment skills.

\begin{tabular}{clcc}
\hline No. & Items & WM & Verbal Interpretation \\
\hline 1 & $\begin{array}{l}\text { Check students' understanding, processes, and products by asking comprehension } \\
\text { questions and requiring practical application of skills }\end{array}$ & 4.15 & Competent \\
2 & $\begin{array}{l}\text { Measure students' progress systematically using a variety of appropriate assessment } \\
\text { methods and instruments }\end{array}$ & 4.03 & Competent \\
& $\begin{array}{l}\text { Provide feedback about students' performance and making specific recommendations for } \\
\text { improvement }\end{array}$ & 4.22 & Very Competent \\
& $\begin{array}{l}\text { Use assessment results to determine if objectives were met and/or if re-teaching is } \\
\text { necessary }\end{array}$ & 4.18 & Competent \\
& Assess students' progress in relation to the basic learning competencies identified in the & 3.93 & Competent \\
6 & national curriculum & 4.33 & Very Competent \\
7 & Systematically record students' achievements & 4.03 & Competent \\
8 & Make use of authentic assessment forms & 3.98 & Competent \\
Average Weighted Mean & 4.10 & Competent \\
\hline
\end{tabular}

Samantha: "Authentic assessment is timeconsuming so PST sticks to traditional assessment which utilizes pencil-and-paper strategy."

To stay current in the teaching profession, the PSTs obtain inputs through technology, co-teachers and students. With the advent of technological innovations in teaching and learning, PSTs need to be equipped with updates and trends in technology as well as their uses and advantages in teaching and learning. It was supported that student teachers and their cooperating teachers have to follow technological innovations as they play an important role in using new technology to enhance the learning of their students. In this way, teachers become an important element in the education of children in the use of technology (Kabadayi, 2006). While there are many debates as regards the effectiveness of technology-aided instruction for instance, it cannot be denied that the massive use of technologyaided instructional materials significantly affected the way teaching and learning are facilitated. PSTs need to recognize the importance of strengthening complementarity of traditional and non-conventional methods of teaching and learning especially now that digital natives comprise the majority of learners in their target classes.

Another important thing to consider is reviewing teaching philosophies and theories. To be updated and adept with activities to be used in class, PSTs need to assess their own philosophies in teaching. Most of the seasoned teachers have mastered the science and art of teaching because they have truly identified and lived their philosophies about education.

Additionally, familiarization of the K-12 curriculum especially for junior and senior high school is essential. After passing the licensure examination, JRU pre-service teachers prefer to work in either public or private schools.
Teaching abroad is also a part of their mindset. Other than this, they intend to earn their master's degree.

To further illustrate the PSTs pedagogical skills, student performance assessment skills, and classroom management skills, a radar chart was utilized as presented in Figure 2. The idea is that, the more perfect the triangle in the chart, the better profile for the PSTs in terms of their identified competencies. In this case, the area of strength of the PSTs' competencies lies in their classroom management skills (WM: 4.17), followed by their pedagogical skills (WM: 4.13), and student performance assessment skills (WM: 4.10).

However, as regards the extent in employing their pedagogical skills, student performance assessment skills, and classroom management skills, the radar chart as presented in Figure 3 says otherwise.

It can be deduced from Figure 3 that student performance skills (WM: 4.30) is mostly employed compared to their classroom management skills (WM: 4.08) and pedagogical skills (WM: 4.07). Generally, the competencies are employed to a "Great extent".

Using ANOVA, it was found out that the pedagogical skills, student performance assessment skills, and classroom management skills are not significantly related (Table 5), hence the null hypothesis is accepted when tested at $\alpha$ of 0.05 level of significance since the p-value obtained was 0.6988 and the $F$ value was at 0.3613 . This means that being competent in classroom management skills does not necessarily mean one being competent in pedagogical skills or student performance assessment skills and vice versa.

\section{If there is any, how significant is the relationship of the pedagogical, student performance assessment, and classroom management skills of the pre-service teachers?}

To validate the ANOVA results, T-test was employed. 


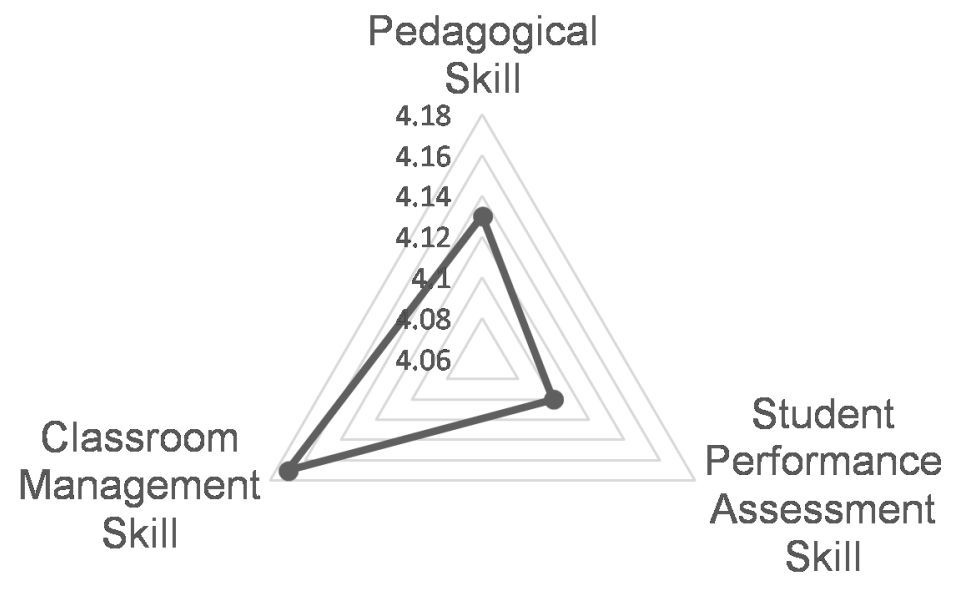

Figure 2. Weighted means of the pedagogical skills, student performance assessment skills, and classroom management skills of the pre-service teachers.

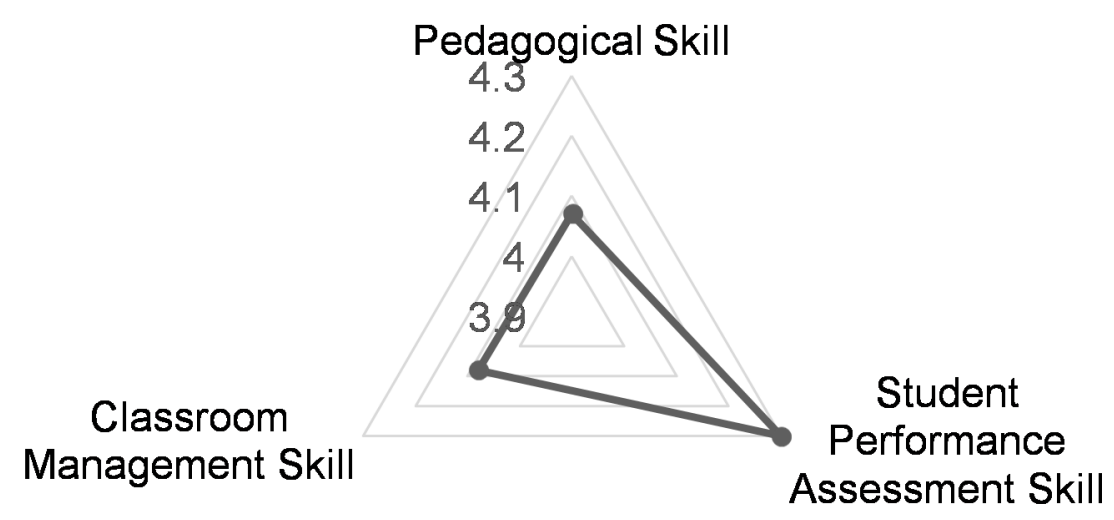

Figure 3. Extent of employing the pre-service teachers' pedagogical skills, student performance assessment skills, and classroom management skills.

Table 5. Relationship between pedagogical skills, student performance assessment skills, and classroom management skills.

\begin{tabular}{lccccc}
\hline Competencies & df & SS & MS & F & P-value \\
\hline $\begin{array}{l}\text { Pedagogical Skills } \\
\begin{array}{l}\text { Student Performance Assessment Skills } \\
\text { Classroom Management Skills }\end{array}\end{array}$ & 2 & 0.030 & 0.015 & 0.3613 & 0.6988 \\
\hline
\end{tabular}

The two-tailed $P$ value equals 0.9250 between the pedagogical skills and student performance assessment skills (t value: 0.0950). By conventional criteria, this difference is considered to be not statistically significant. Meanwhile, the pedagogical skills and classroom management skills ( $t$ value: 0.1570 ), the T-test results shows that the two-tailed $P$ value equals 0.8761 . This also means that the difference between the variables tested is considered to be not statistically significant. Lastly, when student performance assessment skills and classroom management skills (t value: 0.2107 ) were compared by using T-test, the $\mathrm{P}$ value equals 0.8349 which means not statistically significant.

It is understood therefore that when the pre-service teachers are competent in terms of their pedagogical skill according to their assessment, it does not necessarily mean that they are also competent in terms of their student assessment and classroom management skills and vice versa. This goes to show that they can be competent in other identified and assessed competencies 
but could not necessarily mean they are weak in other sets of competencies identified and assessed. The study of König and Kramer (2016) found out that classroom management expertise can be empirically separated from general pedagogical knowledge, although the two constructs are positively inter-correlated.

\section{Challenges encountered by the pre-service teachers in employing their pedagogical, student performance assessment, and classroom management skills}

The PSTs cited several challenges encountered in the application of their pedagogical skills. These include: 1) getting the attention of the students if they are not interested; 2) difficulty in dealing with students who ask irrelevant questions, 3) difficulty in delivering the topic to the students even when prepared, 4) addressing different levels of comprehension, unfamiliarity with motivating factors of students, 5) age gap, 6) poor foundation on pedagogical principles and development theories in child learning, 7) inability to relate theory into practice; and 8.) no creativity in instructional delivery with full consideration to diverse learners.

PSTs also enumerated the following challenges regarding their student performance assessment skills: 1) giving more paper-and-pencil tests; 2) limited authentic assessment tools; 3) views authentic assessment as time-consuming; 4) multiple intelligence is not considered in assessing learning; 5) ensured lesson but evaluation is not being made; 6) recording of quizzes; 7) group performance grading; and 8) inability in creating rubrics to assess learning. Lastly, in terms of classroom management, the PSTs mentioned that they are challenged by: 1) inability to control noise, 2) overly sensitivity to noise, 3) difficulties in handling sarcastic and disrespectful students, 4) soft voice and no authority to control, 5) inconsistency in administering daily tasks, 6) overlooked classroom cleanliness due to time constraint.

Like professional teachers, the PSTs need to establish resilience in facing the adversities and challenges of the $21^{\text {st }}$ century classroom. As suggested by Padagas (2016), Colleges of Education should continuously develop their students as resilient teachers and emphasize the greatest potential for success and longterm commitment and loyalty to the teaching profession once they make resilience as a mindset or a way of life.

\section{CONCLUSION AND RECOMMENDATIONS}

The need to prepare the PSTs in their actual work field is imperative. Higher Education Institutions (HEls) need to double their efforts to keep improvements in the way instruction is delivered to the future teaching workforce. It is indispensable to note that preparing the PSTs require tedious amount of commitment and passion as well as adequate resources. It is above all the responsibility of
HEls to deliver quality education so that the PSTs become living testimonies to the HEls' desired ends or vision. The realization of the aspirations of HEls to develop useful and responsible citizens and human capital depends on the way they value and deliver what are due to the target learners such as the PSTs. At the end of the day, regardless of degrees conferred, every graduate is essential to nation building.

The study revealed that the PSTs were generally competent in the three sets of competencies namely, pedagogical skills, student performance assessment skills, and classroom management skills, but the extent of employing all these in their WBLE says otherwise. The competencies, too, were not significantly related. Moreover, several challenges that beset the PSTs were identified; hence, the formulation of the Triangle of PreService Teachers' Attributes and Characteristics, and Competencies in a WBLE must be used as basis in planning for the teaching and learning delivery of the PSTs.

It is also recommended that the university must intensify its curriculum improvement particularly in the exposure of PSTs to their WBLE to improve their competencies. Likewise, an improvement in the preservice authentic and real-life learning processes and experiences on employing their pedagogical, classroom management and student performance assessment skills must also be reinforced.

Meanwhile, this study can be replicated using a larger group of respondents. It is also suggested that comparative studies be conducted across different countries to make differentiations in the ways PSTs are being equipped to modestly face the challenges of the $21^{\text {st }}$ century classroom.

\section{ACKNOWLEDGEMENTS}

The Guided Research Project of Jose Rizal University under the tutelage of Dr. Vicente K. Fabella and Dr. Barbara Wong-Fernandez supported this work. The author gratefully acknowledges the unending support provided by Jose Rizal University to complete the study. Special thanks to all the research participants.

\section{REFERENCES}

Ager, M. (2016). DepEd 'hunting' for more Math, English teachers. September 26, 2016, Retrieved from http://newsinfo.inquirer.net/819003/deped-hunting-for-more-mathenglish-teachers.

Akkus, Z. (2015). Activity-based teaching in social studies education: An action research. Educational Research and Reviews, 10(14): 1911-1921.

Aslan, A., and Zhu, C. (2015). Pre-Service Teachers' Perceptions of ICT Integration in Teacher Education in Turkey. Turkish Online Journal of Educational Technology-TOJET, 14(3): 97-110.

Career and Technical Education (n.d.). Benefits of work-based learning. Public Schools of North Carolina, State Board of Education, 
Department of Public Instruction, Retrieved from http://www.ncpublicschools.org/cte/curriculum/work-based/benefits/.

Cheng, L., Wu, Y., and Liu, X. (2015). Chinese university students' perceptions of assessment tasks and classroom assessment environment. Language Testing in Asia, 5(1): 1-17.

Dignath, C., and Büttner, G. (2018). Teachers' direct and indirect promotion of self-regulated learning in primary and secondary school mathematics classes-insights from video-based classroom observations and teacher interviews. Metacognition and Learning, 13(2): 127-157.

Flower, A., McKenna, J. W., and Haring, C. D. (2017). Behavior and classroom management: Are teacher preparation programs really preparing our teachers? Preventing School Failure: Alternative Education for Children and Youth, 61(2): 163-169.

Hathaway, T., and Fletcher, P. (2018). An investigation of K-6 preservice teachers' ways of experiencing the teaching of diverse learners using phenomenography. Educational Research for Policy and Practice, 17(2): 83-104.

Irmawati, D. K., Widiati, U., and Cahyono, B. Y. (2017). How do Indonesian professional English teachers develop their pedagogical competence in teaching implementation? Arab World English Journal, 8(2): 293-307.

Johnston, V., and Collum, D. (2018). A Multi-University: Use of simSchool to Increase Pre-Service and In-Service Teachers' Understanding of the Use of Differentiated Instruction and the Understanding of Classroom Management and Behavior. In Society for Information Technology and Teacher Education International Conference (pp. 1550-1556). Association for the Advancement of Computing in Education (AACE).

Kaarby, K. M. E., and Lindboe, I. M. (2016). The workplace as learning environment in early childhood teacher education: an investigation of work-based education. Higher Education Pedagogies, 1(1): 106-120.

Kabadayi, A. (2006). Analyzing pre-school student teachers' and their cooperating teachers' attitudes towards the use of educational technology. Turkish Online Journal of Educational Technology, 5(4): 3-10.

Kabadayi, A. (2010). Investigating demographic characteristics and teaching perceptions of Turkish preschool teachers. Early Child Development and Care, 180(6): 809-822.

Kabadayı, A. (2015). Analysing prospective preschool teachers' reasons and motives for entering a teaching career. Didactica Slovenica-Pedagoska Obzorja, 30(2): 103-122.

Khorooshi, P., Isfahany, A. R. N., Mirshahjafari, S. E., Mosapour, N. (2016). Explaining ideal teacher competences in the Islamic Republic of Iran-Based on the Revolutionary documentations of its education and pedagogical system. International Education Studies, 9(12): 148156.

König, J., and Kramer, C. (2016). Teacher professional knowledge and classroom management: On the relation of general pedagogical knowledge (GPK) and classroom management expertise (CME). ZDM, 48(1-2): 139-151.

Morgan, H. (2014). Maximizing student success with differentiated learning. The Clearing House: A Journal of Educational Strategies, Issues and Ideas, 87(1): 34-38.

Padagas, R. C. (2016). Resilience quotient, job satisfaction and organizational commitment of public secondary school teachers of the division of city schools of Mandaluyong City. Proceedings Journal of Education, Psychology and Social Science Research, 3(2): 182.

Popescu, A. M., and Stefan, M. A. (2014). Training the educator for methodological alternatives and paradigm changes in education. Revista De Stiinte Politice, 43: 183-194.

Schmidt, M. (2005). Preservice string teachers' lesson-planning processes: An exploratory study. Journal of Research in Music Education, 53(1): 6-25.

SEAMEO INNOTECH (2010). Teaching Competency Standards in Southeast Asian Countries: Eleven Country Audit, SEAMEO INNOTECH Regional Education Project (SIREP), Retrieved from https://www.scribd.com/document/107124225/TeachingCompetency-Standards-in-Southeast-AsianCountries?cv=1.
Tan, E. (2018). Effects of two differently sequenced classroom scripts on common ground in collaborative inquiry learning. Instructional Science, 1-27.

Van Der Valk, T. A. E., and Broekman, H. (1999). The lesson preparation method: A way of investigating pre-service teachers' pedagogical content knowledge. European Journal of Teacher Education, 22(1): 11-22.

Villarroel, V., Bloxham, S., Bruna, D., Bruna, C., and Herrera-Seda, C. (2018). Authentic assessment: creating a blueprint for course design. Assessment and Evaluation in Higher Education, 43(5): 840854.

Wallin, A., Nokelainen, P., and Mikkonen, S. (2018). How experienced professionals develop their expertise in work-based higher education: a literature review. Higher Education, 1-20.

Zlatkin-Troitschanskaia, O., Pant, H. A., and Coates, H. (2016). Assessing student learning outcomes in higher education: Challenges and international perspectives. Assessment \& Evaluation in Higher Education, 41(5): 655-661.

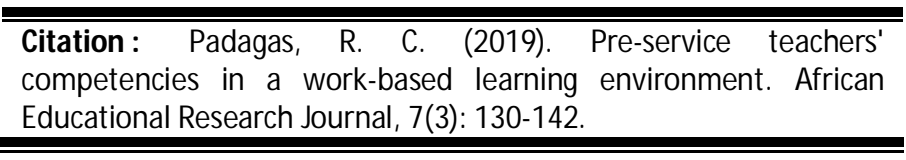

